\title{
The effect of propylene glycol and glycerol on carbohydrate and lipid metabolism in rabbits - short communication
}

\author{
Robert Kupczyński ${ }^{1 *}$, Michal Bednarski² ${ }^{2}$ and Tomasz Piasecki² \\ ${ }^{1}$ Department of Environmental Hygiene and Animal Welfare, Faculty of Biology and Animal Science, Wroclaw \\ University of Environmental and Life Sciences, Wroclaw, Poland \\ ${ }^{2}$ Department of Epizootiology with Clinic of Birds and Exotic Animals, Faculty of Veterinary Medicine, Wroclaw \\ University of Environmental and Life Sciences, Wroclaw, Poland
}

KUPCZYŃSKI, R., M. BEDNARSKI, T. PIASECKI: The effect of propylene glycol and glycerol on carbohydrate and lipid metabolism in rabbits - short communication. Vet. arhiv 90, 307-316, 2020.

\section{ABSTRACT}

This study examined the effects of glycogenic precursors (propylene glycol and glycerol) on lipid and carbohydrate metabolism of rabbit does fed a restricted diet. The study included 48 females of the Hyplus genetic line, divided into primiparous and multiparous groups. On the $4^{\text {th }}$ day of the restricted diet, the rabbits were orally administered propylene glycol (PG) or glycerol (G), $2 \mathrm{~mL} / \mathrm{kg}$ body weight ${ }^{0.75}$. Blood samples were collected immediately prior to administration of the glycogenic precursors and 30,60,90,180, and 360 minutes thereafter. Serum concentrations of glucose, non-esterified fatty acids (NEFA), and $\beta$-hydroxybutyric acid were determined. Following the use of both glycogenic precursors, glucose concentration increased after $30 \mathrm{~min}$., which was maintained until the end of the experiment. A significant $(\mathrm{P}<0.01)$ decrease in NEFA occurred 120 min after $\mathrm{PG}$ was given to primiparous and multiparous does, and remained low up to 360 min after administration. For glycerol, the decrease in NEFA occurred later after $360 \mathrm{~min}$. The mean glucose concentration for the whole period was lower in multiparous females, and higher in primiparous ones. We revealed that both propylene glycol and glycerol showed the evident effect of lipolysis inhibition and gluconeogenesis stimulation, which can be used in practice (e.g. lactation, reproduction).

Key words: rabbit; metabolic status; propylene glycol; glycerol

\section{Introduction}

During the perinatal period and lactation, significant energy deficits are observed in rabbits, especially in highly-productive genetic lines. Consumption of feed during this period is frequently insufficient to meet the demands of lactation and subsequent pregnancy (FORTUN-LAMOTHE et

al., 1999; XICCATO et al., 2004). This is reflected by the loss of weight and mobilization of adipose reserves. The loss of adipose tissue is $32 \%$ in rabbits on a restricted diet (covering $85 \%$ of energetic requirement) and up to $66 \%$ in lactating does fed $a d$ libitum (FORTUN-LAMOTHE and PRUNIER,

\footnotetext{
*Corresponding author:

Robert Kupczyński, Department of Environment Hygiene and Animal Welfare, Wroclaw University of Environmental and Life Sciences, Chelmonskiego 38 c, 51-630 Wroclaw, Poland, Phone: +48 723205 941; Fax: +48 72 3205866; E-mail: robert.kupczynski@upwr.edu.pl
} 
1999). The severity of energy deficit observed in female rabbits during lactation is modulated by the date of weaning, and ranges between -2.68 MJ and $-6.65 \mathrm{MJ}$ at 21 and 32 days postpartum, respectively (XICCATO et al., 2004). Importantly, the energy deficiency is higher in primiparous than in multiparous does (XICCATO et al., 2004). Most previous studies have focused on nutritional strategies to prevent the negative energy balance, especially through the use of supplemental fat (XICCATO et al., 1999; PASCUAL et al., 2000; PENCHEV et al., 2006). The effect of weaning time on the reduction of fat mobilization was also evaluated (FEUGIER and FORTUN-LAMOTHE, 2006; GARCIA-GARCIA et al., 2012).

The possibility of nutritional intervention, especially with the use of glucoplastic substances to attenuate the deficit of energy has been the subject of extensive research in dairy cows. An array of studies have addressed the application of propylene glycol (CHRISTENSEN et al., 1997; KUPCZYŃSKI et al., 2005; GRUMMER, 2008; CHUNG et al., 2009) or glycerol (CHUNG et al., 2007; OSBORNE et al., 2009; ADAMSKI et al., 2011) during the transition period in cows. Propylene glycol (PG) is a glycogenic precursor, rapidly absorbed from the rumen for gluconeogenesis in the liver, which has been used for many years for both treatment and prevention of ketosis before and after parturition in cows (GRUMMER, 2008). Propylene glycol caused an increase in glucose levels and a reduction in $\beta$-hydroxybutyric acid (BHBA) and non-esterified fatty acid (NEFA) concentrations in the blood of cows (KUPCZYŃSKI et al., 2005, RIZOS et al., 2008). Only a few studies have investigated the use of glucoplastic substances in rabbit nutrition (LUZI et al., 2001; RETORE et al., 2012; ARIASÁLVAREZ et al., 2013). In rabbits, PG seems to have positive effects on sexual receptivity and fertility, but these results are not conclusive (LUZI et al., 2001; ARIAS-ÁLVAREZ et al., 2013).

While there have been some attempts of both propylene glycol and glycerol application in large-scale rabbit farms, their use has not been a subject of detailed research related to metabolic response. There are only a few studies indicating the possibility of glycerol use in rabbit feeding (RETORE et al., 2012). The aim of the study was to analyze the effect of glycogenic precursors (propylene glycol and glycerol) on lipid and carbohydrate metabolism in female rabbits fed a restricted diet. We hypothesized that the metabolic effect in rabbits is similar to that in dairy cows.

\section{Materials and methods}

Experimental design. The study included 48 rabbit does of the Hyplus genetic line ( $q$ Hyplus $19 \times \curvearrowright$ PS Hyplus 39), both multiparous does (with a history of 4-6 pregnancies, 13-15 months of age) and younger females after their first parturition $(8$ months of age). The females were taken from the farm to take part in the experiment on the day of weaning their kits on the $35^{\text {th }}$ day after delivery. The rabbits were not used for reproduction (from the last parturition). All procedures for this trial were approved by the $2^{\text {nd }}$ Local Ethical Committee for Experiments on Animals in Wrocław (No 43/2006). All rabbits were housed under the same environmental conditions in the vivarium at the Department of Epizootiology with Clinic of Birds and Exotic Animals, Wrocław University of Environmental and Life Sciences.

The rabbits were housed in individual cages $(0.6 \times 0.7 \times 0.45 \mathrm{~m})$. The mean air temperature was $20.8 \pm 2.0{ }^{\circ} \mathrm{C}$ throughout the entire period of the study, and the relative humidity and air exchange rate amounted to $57.6 \pm 4.3 \%$ and $16-\mathrm{h}$ light $/ 8$-h dark photoperiod. During the adaptation period, the females were fed a commercial diet in the form of pellets and classical agricultural hay, both offered ad libitum. The chemical composition of the experimental diet is shown in Table 1. The chemical analysis of diets was determined according to the AOAC (2005). Gross energy was determined by adiabatic bomb calorimeter (KL 12Mn, PrecyzjaBit PPHU, Poland). All the animals underwent a 14day adaptation period followed by a 3-day period of restricted feeding (50\% of daily pellet and hay intake). The rabbits were fed manually at 8:30 a.m. during the restriction period. Hay and pellets were given every day through separate feeders at the same time. 
R. Kupczyński et al.: The effect of propylene glycol and glycerol on carbohydrate and lipid metabolism in rabbits - short communication

Table 1. Ingredients and chemical composition of the experimental diet

\begin{tabular}{|c|c|c|c|c|}
\hline \multicolumn{2}{|c|}{ Composition of feed mixtures, pellets $(\%)$} & \multicolumn{3}{|c|}{ Chemical composition ( $\%$ of DM) } \\
\hline Wheat bran & 8.5 & & Pellets $^{\mathrm{c}}$ & Hay $^{\mathrm{c}}$ \\
\hline Sunflowers husk & 1.0 & Dry matter & 89.03 & 10.10 \\
\hline Beet molasses & 5.0 & Total protein $(\%)$ & 16.69 & 10.90 \\
\hline Dried alfalfa $(18 \% \mathrm{CP})$ & 21.5 & Crude fiber $(\%)$ & 18.11 & 25.02 \\
\hline Wheat & 11.5 & Crude fat & 3.58 & 2.06 \\
\hline Soybean meal (44\% CP) & 13.5 & Crude ash $(\%)$ & 6.21 & 7.70 \\
\hline Barley & 10.5 & Gross energy $(\mathrm{MJ} / \mathrm{kg})$ & 15.56 & 3.15 \\
\hline Oat & 11.5 & & & \\
\hline Corn & 7.5 & & & \\
\hline Rapeseed meal & 2.5 & & & \\
\hline Soybean oil & 1.0 & & & \\
\hline Dried brewer's yeast & 2.5 & & & \\
\hline Calcium carbonate & 1.0 & & & \\
\hline Dicalcium phosphate & 1.0 & & & \\
\hline $\mathrm{NaCl}$ & 0.5 & & & \\
\hline Mineral-vitamin premix $^{\mathrm{a}}$ & 1.0 & & & \\
\hline
\end{tabular}

a - Provided per kilogram of pellets: $66.00 \mathrm{mg}$ robenidine hydrochloride, $10000 \mathrm{IU}$ of vitamin A; $2500 \mathrm{IU}$ of vitamin $\mathrm{D}_{3} ; 60 \mathrm{mg}$ of Vitamin E; $5 \mathrm{mg}$ of $\mathrm{Cu} ; 50 \mathrm{mg}$ of Fe; $0.5 \mathrm{mg}$ of I; $0.2 \mathrm{mg}$ of Se; $65 \mathrm{mg}$ of Zn; $26 \mathrm{mg}$ of Mn (manufacturer's data). Pellets and hay offered ad libitum during adaptation period

Table 2. Body weight, feed intake and the amount of propylene glycol and glycerol administered to rabbits $(\mathrm{n}=8$ per group)

\begin{tabular}{|c|c|c|c|c|c|c|c|c|c|c|}
\hline & \multicolumn{6}{|c|}{ Treatment $^{\mathrm{a}}$} & \multirow[b]{2}{*}{ SEM } & \multicolumn{3}{|c|}{ P-value } \\
\hline & $\mathrm{CP}$ & $\mathrm{CM}$ & PGP & PGM & GP & GM & & Treatment & Parity & $\begin{array}{l}\text { Treatment } \\
\times \text { parity }\end{array}$ \\
\hline $\begin{array}{l}\text { Body weight at start } \\
\text { adaptation period }(\mathrm{kg})\end{array}$ & 3.64 & 4.96 & 3.60 & 4.95 & 3.68 & 4.98 & 0.11 & 0.64 & $<0.01$ & 0.88 \\
\hline $\begin{array}{l}\text { Body weight after } 14 \text { day of } \\
\text { adaptation period }(\mathrm{kg})\end{array}$ & 3.99 & 5.37 & 3.87 & 5.38 & 4.01 & 5.37 & 0.13 & 0.51 & $<0.01$ & 0.43 \\
\hline $\begin{array}{l}\text { Daily pellet intake at } 14 \\
\text { day of adaptation period }(\mathrm{g})\end{array}$ & 183.0 & 203.7 & 181.0 & 205.1 & 185.3 & 204.0 & 2.61 & 0.95 & $<0.01$ & 0.87 \\
\hline $\begin{array}{l}\text { Daily hay intake at } 14 \text { day } \\
\text { of adaptation period }(\mathrm{g})\end{array}$ & 70.0 & 96.0 & 84.0 & 112.0 & 73.0 & 101.0 & 2.33 & 0.01 & $<0.01$ & 0.01 \\
\hline $\begin{array}{l}\text { Body weight after restricted } \\
\text { feeding }(\mathrm{kg})^{\mathrm{b}}\end{array}$ & 3.90 & 5.26 & 3.77 & 5.25 & 3.91 & 5.28 & 0.11 & 0.41 & $<0.01$ & 0.58 \\
\hline $\begin{array}{l}\text { Volume of products } \\
\text { administered (mL/rabbits) }\end{array}$ & $2.8^{*}$ & $3.5^{*}$ & 2.7 & 3.5 & 2.8 & 3.5 & 0.06 & - & - & - \\
\hline
\end{tabular}

a - CP - control primiparous, CM - control multiparous, PGP - propylene glycol primiparous; GM - propylene glycol multiparous, GP - glycerin primiparous, GM- glycerol multiparous; ${ }^{\text {b }}$ - Body weight after 3 days of restrictive feeding; * - Water. 
On the $4^{\text {th }}$ day at 6:00 a.m., the following supplements were administered to fasted animals ( $\mathrm{n}=8$ per group):

- primiparous control rabbits, drinking water $(2$ $\mathrm{mL} / \mathrm{kg}$ body weight ${ }^{0.75}$ ) instead of glycemic precursors $(\mathrm{CP})$;

- control multiparous, drinking water $(2 \mathrm{~mL} /$ $\mathrm{kg}$ body weight ${ }^{0.75}$ ) instead of glycemic precursors $(\mathrm{CM})$;

- primiparous: propylene glycerol $(99.9 \%$ 1.2-propandiol; Over) per os $2 \mathrm{~mL} / \mathrm{kg}$ body weight $^{0.75}$ (PPG);

- multiparous: propylene glycerol (99.9\% 1.2-propandiol; Over) per os $2 \mathrm{~mL} / \mathrm{kg}$ body weight $^{0.75}$ (MPG);

- primiparous: glycerol (99.7\% 1,2,3-propantriol, Over) per os $2 \mathrm{~mL} / \mathrm{kg}$ body weight ${ }^{0.75}$ (PG);

- multiparous: glycerol (99.7\% 1,2,3-propantriol, Over) per os $2 \mathrm{~mL} / \mathrm{kg}$ body weight ${ }^{0.75}$ (MG).

Body weight (bw) and feed intake were determined after the $1^{\text {st }}$ day of acclimation, at the end of the acclimatization period (after 14 days) and on the $3^{\text {rd }}$ day of restrictive feeding. The mean body weight of the studied rabbits and the amounts of the supplements administered are summarized in Table 2.

Blood sampling and analysis. Blood samples from the central auricular artery were obtained at 0 (immediately before administration of propylene glycol or glycerol) and 30,60, 90, 180, and 360 minutes thereafter into tubes without anticoagulant (Sarstedt, Warszawa, Poland). The blood samples were centrifuged at $3000 \mathrm{~g}$ for $10 \mathrm{~min}$ at room temperature ( 2 hours from collection), and the serum samples were frozen $\left(-20{ }^{\circ} \mathrm{C}\right)$ until the analysis. Laboratory analyses were conducted with a Pentra 400 biochemical analyzer (Horiba ABX Diagnostics, France). Serum concentrations of the following compounds were determined:

- glucose: oxidase method with Horiba ABX reagents (Glucose PAP, Cat. No. A11A01679),

- $\beta$-hydroxybutyric acid (BHBA), non-esterified fatty acids (NEFA): enzymatic method with Randox (Ireland) reagents (Cat. No. RB1007, and Cat. No. FA115).
Statistical analysis. The results were subjected to statistical analysis with Statistica ver. 10.0 software. The data are presented as mean values and accompanied by standard error of the means. Body weight and feed intake were analyzed by a twoway ANOVA using Tukey test. Serum biochemistry data were analyzed as repeated measures using the ANOVA procedure of Statistica considering in the statistical model the effects of treatment, beyond the effects of time with their interactions with the treatment. Responses to glucogenic precursors were tested with linear and quadratic contrasts. Differences between means with $\mathrm{P}<0.05$ were accepted as statistically significant differences.

\section{Results}

The body weight (bw) of rabbits at the beginning of the experiment significantly differed between primiparous and multiparous does (Table 2). BW increased after 14 days of adaptation period when ad libitum feeding was applied, and a higher increase in $\mathrm{BW}(\mathrm{P}<0.01)$ was noted for multiparous rabbits. No statistical differences were found in the daily pellet intake between the groups; however, such differences occurred in hay intake $(\mathrm{P}<0.01)$. The reduction in $\mathrm{BW}$ after the restrictive feeding period was lowest in the CP and PGP groups.

The serum concentrations of the biochemical markers studied in the rabbits are summarized in Table 3. Significant differences were noted for treatment and time after supplementation $(\mathrm{P}<0.01)$. Oral administration of $\mathrm{PG}$ caused an increase $(\mathrm{P}<0.05)$ in serum glucose concentration in primiparous and multiparous does, which began after $30 \mathrm{~min}$. The differences between the treatment and control groups at the $60^{\text {th }}$ min were confirmed statistically $(8.36 \mathrm{mmol} / \mathrm{L}$ in PGP and $7.44 \mathrm{mmol} / \mathrm{L}$ in PGM vs. 6.98 in $\mathrm{CP}$ and $6.41 \mathrm{mmol} / \mathrm{L}$ in $\mathrm{CM}$; $\mathrm{P}<0.01$ ). Oral administration of $\mathrm{G}$ exerted a similar glycogenic effect as the concentration of glucose in consecutive samples increased in both groups of rabbits. An increase in the level of glucose was observed $30 \mathrm{~min}$ after glycerol administration. The most pronounced increase (from 6.97 to $8.44 \mathrm{mmol} / \mathrm{L}$ ) was observed in multiparous does following administration of PG (120 min). 


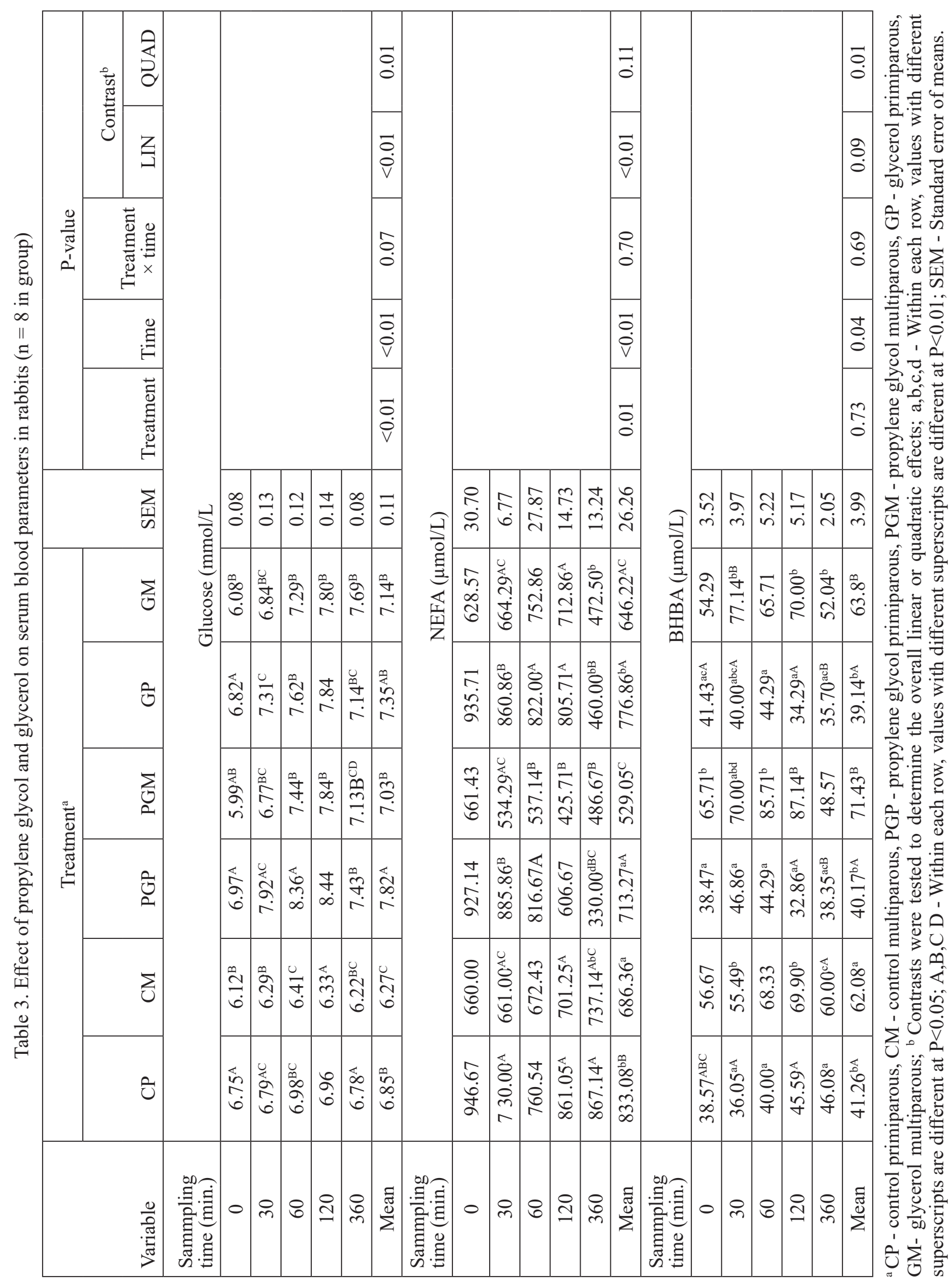


Oral supplementation of $\mathrm{G}$ caused an increase in glucose concentration in the $120^{\text {th }}$ min to the highest values in both primiparous and multiparous does $(7.84 \mathrm{mmol} / \mathrm{L}$ and $7.80 \mathrm{mmol} / \mathrm{L}$, respectively). Considering the glucose concentrations observed during the study period, propylene glycol had a stronger effect in primiparous does while the effect of glycerol was similar in both groups (primiparous, multiparous). However, the mean glucose concentration was lower over the whole period in multiparous does $(7.03 \mathrm{mmol} / \mathrm{L}$ in PGM, $7.14 \mathrm{mmol} / \mathrm{L}$ in $\mathrm{GM})$ than in primiparous ones $(7.82$ $\mathrm{mmoL} / \mathrm{L}$ in PGP, $7.35 \mathrm{mmol} / \mathrm{L}$ in GP). In the case of multiparous does, the mean values in the treatment groups (PGM and GM) were higher compared to CM groups $(\mathrm{P}<0.01)$. The rate of lipolysis, determined from serum NEFA concentration resulting from the restricted diet, was more enhanced in primiparous than in multiparous does. Differences were noted between the treatment groups. In the $30^{\text {th }} \mathrm{min}$., these differences were especially distinct between the primiparous groups $(885.86 \mu \mathrm{mol} / \mathrm{L}$ in PGP, 860.86 $\mu \mathrm{mol} / \mathrm{L}$ in GP vs. $730 \mu \mathrm{mol} / \mathrm{L}$ in $\mathrm{CP} ; \mathrm{P}<0.01)$. Regardless of the supplement used, the mean NEFA concentrations were lower in multiparous compared to primiparous does. The use of PG caused a significant $(\mathrm{P}<0.01)$ decrease in NEFA after 120 $\mathrm{min}$ in primiparous and multiparous does (to 606.67 $\mu \mathrm{mol} / \mathrm{L}$ in PGP and $425.71 \mu \mathrm{mol} / \mathrm{L}$ in PGM). For $\mathrm{G}$, the decrease in NEFA occurred later, after 360 min. (to $460 \mu \mathrm{mol} / \mathrm{L}$ in $\mathrm{GP}, 472.50 \mu \mathrm{mol} / \mathrm{L}$ in $\mathrm{GM}$ ). The metabolic response, expressed as a reduction in NEFA, was stronger in primiparous does.

Irrespective of age, the feed restriction did not cause enhanced ketogenesis. Administration of $P G$ and $G$ was associated with decreased serum concentrations of BHBA in both primiparous and multiparous does. However, the mean concentration of BHBA was lower in primiparous than in multiparous does. In both control groups, BHBA concentrations consistently increased during the study period (Table 3).

\section{Discussion}

During the postpartum and early lactation periods, rabbits are in a negative energy balance (ATTIA et al., 2006; XICCATO et al., 2004;
MINUTI et al., 2015). WEBER AND REIDY (2012) demonstrated an increase in lipolysis and NEFA concentrations during fasting in nonpregnant rabbits. In our animal model, restrictive feeding was used aimed at lipolysis enhancement. In this study, metabolic changes were caused by a decreased fulfillment of nutritional needs (moderate 3 day restrictive feeding). The experiment evaluated the metabolic response after administration of glucose precursors (PG or $\mathrm{G}$ ) in primiparous and multiparous does.

In the present study, the restricted diet caused an increase in NEFA blood concentrations to high values during the first sampling. According to CORINO et al. (2007), the blood concentration of NEFA in rabbits equaled $293.6 \mu \mathrm{mol} / \mathrm{L}$ and was markedly lower than in our study. Moreover, our study revealed that feed restriction is associated with more enhanced lipolysis in primiparous than in multiparous does. This fact is reflected in the high concentrations of NEFA, which were distinctly higher at the first blood sampling in primiparous than in multiparous does. Nevertheless, in contrast to the present results, concentrations of BHBA showed the reverse trend. Indeed, concentrations of BHBA showed gradual increase in control groups, however, its concentrations were lower in primiparous than multiparous. A previous study indicated that multiparous does were less susceptible to energy deficiency than primiparous does (PASCUAL et al., 2000; ROMMERS et al., 2004). This phenomenon was also reported by PASCUAL et al. (1998) and could be partly related to the incomplete growth of primiparous does. A possible explanation for differences in BHBA concentration is that the ketogenesis is lower or slower in primiparous than multiparous does.

Propylene glycol and glycerol have found widespread use in preventing negative energy balance in cows and in ketosis treatment (KUPCZYŃSKI et al., 2005; KRISTENSEN and RAUN, 2007; GRUMMER, 2008; RIZOS et al., 2008). The experiment was designed to evaluate the effects of glycogenic precursors on the metabolism of female rabbits fed a restricted diet, which leads to a decrease in lipolysis, and to determine whether propylene glycol and glycerol are effective, and 
which substance is more effective in inhibiting lipolysis.

Following the administration of glucoplastic substances, the increase in glucose concentration began within 30-60 min and persisted up to the $360^{\text {th }}$ minute after administration. We observed that the positive effect of glucose concentration was the most pronounced in primiparous does treated with PG. Postpartum oral administration of glycerol in cows increased plasma glucose concentration in the first 4 hours, and tended to increase it over the entire 8-hour period (OSBORNE et al., 2009). In turn, GRUMMER et al., (1994) indicated that plasma concentration of glucose and insulin peaked within 75 and 30 min after glycol drenching, respectively. In our study, this trend was not observed, but glucose concentration at the last sampling was highest after glycol supplementation in primiparous and after glycerol supplementation in multiparous does. The level of blood glucose in rabbits can vary depending on breed and the type of diet (BIRKNER et al., 2005; PENCHEV et al., 2006). In rabbits, glucose concentrations quickly rebounded to normal values. Concentrations increased immediately at the end of the fasting, already within $1 \mathrm{~h}$, upon re-feeding and lasted for the next 4 hours (ATTIA et al., 2006).

In addition, increased blood glucose concentrations can positively affect the reproductive performance of rabbits (ATTIA et al., 2010). However, supplementation of PG from midpregnancy and during lactation seems to induce the adaptation of the embryo metabolism without substantial changes in the maternal metabolism profile, the ovarian response and the number of blastocysts developed (ARIAS-ÁLVAREZ et al., 2013). The available literature lacks studies comparing the effect of PG and G on the carbohydrate-lipid metabolism of rabbits in a single experiment. Only the effect of the use of vegetable and mixed crude glycerol on production indices in growing rabbits was examined (RETORE et al., 2012).

In our study, propylene glycol and glycerol produced a similar final effect in terms of NEFA concentration. In primiparous and multiparous does, propylene glycol acted more quickly and strongly. When propylene glycol was administered,
NEFA decreased significantly after $120 \mathrm{~min}$. In the case of glycol, NEFA only decreased after $360 \mathrm{~min}$. A similar effect was observed in cattle, where a decrease in NEFA after per os administration of PG was already observed in cows over the subsequent 90 min. (RIZOS et al., 2008), while for glycerol, this effect in cows occurred later, after 4 hours (OSBORNE et al., 2009). The decrease in NEFA levels after re-feeding in fasting rabbits was rapid (ATTIA et al., 2006). Interestingly, NEFA only rebounded to normal values (CORINO et al., 2007 ) in primiparous treated with propylene glycol. Other long-term studies with rabbits revealed no differences in serum NEFA concentrations between PG supplemented does and those not supplemented at any time points measured (ARIAS-ÁLVAREZ et al., 2013). When evaluating metabolic processes in rabbits, it is important to account for breed or hybrid line. The genetic selection of does for higher litter size has increased their ability to mobilize body reserves in order to guarantee the nutrients to a high number of kits (MINUTI et al., 2015). Our experimental model indicated that feed restriction enhanced lipolysis more in primiparous than in multiparous does, however the response in terms of glycogenic precursors was greater in primiparous rabbits.

The results obtained for BHBA concentrations were inconclusive. Following the administration of propylene glycol and glycerol, BHBAconcentrations initially increased but then decreased to the initial values (primiparous does) or to below the initial values (multiparous does). These changes were not significant. This phenomenon is interesting in so far as in cattle the effect of decreased BHBA is also not immediate. Per os administration of PG resulted in a decrease in NEFA and BHBA over the subsequent 90 minutes compared to the control animals (RIZOS et al., 2008). A comparison between the two methods of PG supplementation in terms of TMR in cows produced similar results (CHUNG et al., 2009).

\section{Conclusion}

Our findings suggest that a short-term feed restriction causes enhanced lipolysis (increase in NEFA) in primiparous compared to multiparous 
rabbits. Moreover, we revealed that both propylene glycol and glycerol show an evident effect in terms of lipolysis inhibition and gluconeogenesis stimulation. Despite some differences in metabolic response between primiparous and multiparous does, the effect of propylene glycol proved to be quicker and stronger. This result should be tested in field studies on larger groups of animals in production conditions.

\section{Acknowledgements}

Project supported by Wroclaw Centre of Biotechnology, programme: The Leading National Research Centre (KNOW) for years 2014-2018.

\section{References}

ADAMSKI, M., R. KUPCZYŃSKI, G. CHLADEK, D. FALTA (2011): Influence of propylene glycol and glycerin in Simmental cows in periparturient period on milk yield and metabolic changes. Arch. Anim. Breed. 54, 238-248.

DOI: 10.5194/aab-54-238-2011

AOAC International (2005): Official methods of analysis of the Association of Official Analytical Chemists, $18^{\text {th }}$ ed. AOAC, Gaithersburg, MD, USA.

ARIAS-ÁlVAREZ, M., R. M. GARCÍA-GARCÍA, P. L. LORENZO, A. GUTIÉRREZ-ADÁN, O. G. SAKR, A. GONZÁlEZ-BULNES, P. G. REBOLlAR (2013): Embryo gene expression in response to maternal supplementation with glycogenic precursors in the rabbit. Anim. Reprod. Sci. 142, 173-182.

DOI: 10.1016/j.anireprosci.2013.10.001

ATTIA, G., A. BONANNO, G. GALEATI, C. FEDERICI, M. MARANESI, A. GOBBETTI, M. ZERANID, C. BOITI (2006): Hormonal and metabolic adaptation to fasting: effects on the hypothalamicpituitary-ovarian axis and reproductive performance of rabbit does. Dom. Anim. Endocrinol. 31, 105-122.

DOI: 10.1016/j.domaniend.2005.09.006

ATTIA, Y. A, A. E. ABD EL HAMID, F. BOVERA, M. ELSAYED (2010): Oral glucose supplementation improved semen quality and constituents of seminal and blond plasma of NZW buck rabbits in the subtropics. Open Access Anim. Physiol. 2, 81-85.

BIRKNER, E., S. KASPERCZYK, A. KASPERCZYK, J. ZALEJSKA-FIOLKA, K. ZWIRSKA-KORCZALA, B. STAWIARSKA-PIECTA, E. GRUCKA-MAMCZAR (2005): Metabolic and antioxidative changes in liver steatosis induced by high-fat, low-carbohydrate diet in rabbits. J. Physiol. Pharmacol. 56 (Suppl.), 45-58.

CHRISTENSEN, J. O., R. R. GRUMMER, F. E. RASMUSSEN, S. J. BERTICS (1997): Effect of method of delivery of propylene glycol on plasma metabolites of feed-restricted cattle. J. Dairy. Sci. 80, 563-568.

DOI: 10.3168/jds.S0022-0302(97)75971-X

CHUNG, Y. H., N. E. BROWN, C. M. MARTINEZ, T. W. CASSIDY, G. A. VARGA (2009): Effects of rumenprotected choline and dry propylene glycol on feed intake and blood parameters for Holstein dairy cows in early lactation. J. Dairy Sci. 92, 2729-2736.

DOI: $10.3168 /$ jds.2008-1299

CHUNG, Y. H., D. E. RICO, C. M. MARTINEZ, T. W. CASSIDY, V. NOIROT, A. AMES, G. A. VARGA (2007): Effects of feeding dry glycerin to early postpartum holstein dairy cows on lactational performance and metabolic profiles. J. Dairy Sci. 90. 5682-5691.

DOI: $10.3168 /$ jds.2007-0426

CORINO, C., D. P. LO FIEGO, P. MACCHIONI, G. PASTORELLI, A. DI GIANCAMILLO, C. DOMENEGHINI, R. ROSSI (2007): Influence of dietary conjugated linoleic acids and vitamin $\mathrm{E}$ on meat quality, and adipose tissue in rabbits. Meat Sci. 76, 19-28.

DOI: 10.1016/j.meatsci.2006.10.007

FEUGIER, A., L. FORTUN-LAMOTHE (2006): Extensive reproductive rhythm and early weaning improve body condition and fertility of rabbit does. Anim. Res. 55, 459470.

DOI: 10.1051/animres:2006025

FORTUN-LAMOTHE, L., A. PRUNIER (1999): Effects of lactation, energetic deficit and remating interval on reproductive performance of primiparous rabbit does. Anim. Prod. Sci., 55, 289-298.

DOI: $10.1016 /$ S0378-4320(99)00020-2

FORTUN-LAMOTHE, L., A. PRUNIER, G. BOLET, F. LEBAS (1999): Physiological mechanism involved in the effects of concurrent pregnancy and lactation on foetal growth and mortality in the rabbit. Livest. Prod. Sci. 60, 229-241.

DOI: 10.1016/S0301-6226(99)00096-2

GARCIA-GARCIA, R. M., O. G. SAKR, M. ARIASALVAREZ, B. VELASCO, P. L. LORENZO, P. G. REBOLLAR (2012): Metabolic and reproductive status are not improved from 11 to 25 day post-partum in nonweaned primiparous rabbit does. Anim. Reprod. Sci. 131, 100-106.

GRUMMER, R. R. (2008): Nutritional and management strategies for the prevention of fatty liver in dairy cattle. Vet. J. 176, 10-20.

DOI: $10.1016 /$ j.tvj1.2007.12.033

GRUMMER, R. R., J. C. WINKLER, S. J. BERTICS, V. A. STUDER (1994): Effect of propylene glycol dosage during feed restriction on metabolites in blood of prepartum Holstein heifers. J. Dairy Sci. 77, 3618-3623.

DOI: 10.3168/jds.S0022-0302(94)77306-9 
KRISTENSEN, N. B., B. M. L. RAUN (2007): Ruminal and intermediary metabolism of propylene glycol in lactating holstein cows. J. Dairy Sci. 90, 4707-4717.

DOI: $10.3168 /$ jds.2007-0295

KUPCZYŃSKI, R., W. JANECZEK, K. POGODASEWERNIAK (2005): Studies on the use of different doses of propylene glycol in dairy cows during the periparturient period. Medycyna Weter. 61, 194-199.

LUZI, F., S. BARBIERI, C. LAZZARONI, C. CAVANI, M. ZECHINI, C. CRIMELLA (2001): Effects of Propylene Glycol addition in drinking water on reproduction performance of rabbit breeding does. World Rabbit Sci. 9, $15-18$.

MINUTI, A., P. BANI, F. PICCIOLI-CAPPELLI, O. UBOLDI, N. BACCIU, E. TREVISI (2015): Metabolic and biochemical changes in plasma of the periparturient rabbit does with different litter size. Animal 9, 614-621.

DOI: $10.1017 / \mathrm{S} 1751731114002675$

Osborne, V. R., N. E. ODOnGO, J. P. CANT, K. C. SWANSON, B. W. MCBRIDE (2009): Effects of supplementing glycerol and soybean oil in drinking water on feed and water intake, energy balance, and production performance of periparturient dairy cows. J. Dairy Sci. 92, 698-707.

DOI: $10.3168 /$ jds.2008-1554

PASCUAL, J. J., C. CERVERA, E. BLAS, J. FERNANDEZCARMONA (1998): Effect of high fat diets on the performance and food intake of primiparous and multiparous rabbit does. Anim. Sci. 66, 491-499.

DOI: $10.1017 / \mathrm{S} 1357729800009668$

PASCUAL, J. J., C. CERVERA, J. FERNANDEZ-CARMONA (2000): The effect of dietary fat on the performance and body composition of rabbits in their second lactation. Anim. Feed Sci. Technol. 86, 191-203.

DOI: $10.1016 / \mathrm{S} 0377-8401(00) 00166-8$

PENCHEV, G., I. N. KANELOV, S. S. DIMITROVA, Y. I. ILIEV, S. I. TANEV, T. M. GEORGIEVA, B. L. BIVOLARSKI, E. G. VACHKOVA, I. I. GRIGOROV (2006): An experimental model for evaluation of glucose tolerance in Rabbit. Bulg. J. Vet. Med. 1, 27-35.
RETORE, M., C. SCAPINELLO, A. E. MURAKAMI, I. G. ARAUJO, B. PONCIANO NETO, K. D. S. FELSSNER, A. F. G. OLIVEIRA (2012). Nutritional evaluation of vegetable and mixed crude glycerin in the diet of growing rabbits. Rev. Bras. Zootec. 41, 333-340.

DOI: $10.1590 / \mathrm{S} 1516-35982012000200015$

RIZOS, D., D. A. KENNY, W. GRIFFIN, K. M. QUINN, P. DUFFY, F. J. MULLIGAN, J. F. ROCHE, M. P. BOLAND, P. LONERGAN (2008): The effect of feeding propylene glycol to dairy cows during the early postpartum period on follicular dynamics and on metabolic parameters related to fertility. Theriogenology 69, 688-699.

DOI: 10.1016/j.theriogenology.2007.12.001

ROMMERS, J. M., R. MEIJERHOF, J. P. T. M. NOORDHUIZEN, B. KEMP (2004): Effect of feeding program during rearing and age at first insemination on performances during subsequent reproduction in young rabbit does. Reprod. Nutr. Dev. 44, 321-332.

DOI: $10.1051 /$ rnd:2004037

WEBER, J. M., S. P. REIDY (2012): Extending food deprivation reverses the short-term lipolytic response to fasting: role of the triacylglycerol/fatty acid cycle. J. Exp. Biol. 215, 1484-1490.

DOI: $10.1242 /$ jeb.062992

XICCATO, G., M. BERNARDINI, C. CASTELlini, A. DALLE ZOTTE, P. I. QUEAQUE, A. TROCINO (1999): Effect of postweaning feeding on the performance and energy balance of female rabbits at different physiological states. J. Anim. Sci. 77, 416- 426.

XICCATO, G., A. TROCINO, A. SARTORI, P. I. QUEAQUE (2004): Effect of parity order and litter weaning age on the performance and body energy balance of rabbit does. Livest. Prod. Sci. 85, 239-251.

DOI: $10.1016 / \mathrm{S} 0301-6226(03) 00125-8$

Received: 6 February 2019

Accepted: 12 September 2019

\section{KUPCZYŃSKI, R., M. BEDNARSKI, T. PIASECKI: Učinak propilen-glikola i glicerola na metabolizam ugljikohidrata i masti u kunića - kratko priopćenje. Vet. arhiv 90, 307-316, 2020. \\ SAŽETAK}

U ovom je radu istraživan učinak glikogenskih pretskazatelja (propilen-glikola i glicerola) na metabolizam masti i ugljikohidrata u kunića hranjenih restriktivnim obrocima. U istraživanje je uključeno 48 ženki genetičke linije Hyplus, podijeljenih u skupine s obzirom na to jesu li primipare ili multipare. Četvrti dan restriktivne hranidbe kunićima je oralno primijenjen propilen-glikol (PG) ili glicerol (G) u dozi od $2 \mathrm{~mL} / \mathrm{kg}$ tjelesne mase, ${ }^{0,75}$. Uzorci krvi prikupljeni 
su neposredno prije primjene glikogenskih pretskazatelja te 30,60, 90, 180 i 360 minuta poslije njihove primjene. Određene su serumske koncentracije glukoze, neesterificiranih masnih kiselina (NEFA) i beta-hidroksimaslačne kiseline. Primjenom obaju glikogenskih pretskazatelja, koncentracija glukoze porasla je nakon 30 minuta i ta se vrijednost zadržala do kraja istraživanja. Znakovito smanjenje $(\mathrm{P}<0,01)$ NEFA-e bilo je 120 minuta nakon što je PG primjenjen kod primipara i multipara, te je ostao nizak do 360 minuta nakon primjene. Davanjem glicerola vrijednost NEFA-e smanjila se poslije 360 minuta. Srednja vrijednost glukoze u cijelom tom razdoblju bila je niža u multipara, a viša u primipara. Pokazalo se da i propilen-glikol i glicerol imaju učinak lipolitičke inhibicije i stimulacije glukoneogeneze, što se može primijeniti u praksi, primjerice tijekom laktacije i reprodukcije kunića.

Ključne riječi: kunić; metabolički status; propilen-glikol; glicerol 